\title{
Incrimination of Anopheles (Nyssorhynchus) rangeli and An. (Nys.) oswaldoi as natural vectors of Plasmodium vivax in Southern Colombia
}

\author{
Martha L Quiñones/++, Freddy Ruiz/*, David A Calle, Ralph E Harbach*, \\ Holmes F Erazo**, Yvonne-Marie Linton*/+
}

\begin{abstract}
Programme for the Study and Control of Tropical Diseases, Faculdad de Medicina, Universidad de Antioquia, Medellín, Colombia *Mosquitoes Programme, Department of Entomology, The Natural History Museum, London, England, UK **División Administrativa de Salud, Putumayo, Colombia
\end{abstract}

Malaria transmission in the Southern Colombian state of Putumayo continues despite the absence of traditional vector species, except for the presence of Anopheles darlingi near the southeastern border with the state of Amazonas. In order to facilitate malaria vector incrimination in Putumayo, 2445 morphologically identified Anopheles females were tested for natural infection of Plasmodium vivax by ELISA. Specimens tested included An. apicimacula $(n$ $=2)$, An. benarrochi $B(n=1617)$, An. darlingi $(n=29)$, An. mattogrossensis $(n=7)$, An. neomaculipalpus $(n=7)$, An. oswaldoi $(n=362)$, An. peryassui $(n=1)$, An. punctimacula $(n=1)$, An. rangeli $(n=413)$, and An. triannulatus $(n=6)$. Despite being overwhelmingly the most anthropophilic species in the region and comprising $66.1 \%$ of the mosquitoes tested, An. benarrochi $B$ was not shown to be a vector. Thirty-five An. rangeli and one An. oswaldoi were naturally infected with P. vivax VK210. Sequence data were generated for the nuclear second internal transcriber space region of 31 of these 36 vivax positive mosquitoes (86.1\%) to confirm their morphological identification.

An. oswaldoi is known to be a species complex in Latin America, but its internal taxonomy remains unresolved. Herein we show that the An. oswaldoi found in the state of Putumayo is genetically similar to specimens from the state of Amapa in Brazil and from the Ocama region in the state of Amazonas in Venezuela, and that this form harbors natural infections of P. vivax. That An. rangeli and this member of the An. oswaldoi complex are incriminated as malaria vectors in Putumayo, is a novel finding of significance for malaria control in Southern Colombia, and possibly in other areas of Latin America.

Key words: Anopheles rangeli - Anopheles oswaldoi - Anopheles benarrochi B - ELISA - Colombia

Anopheles (Nyssorhynchus) albimanus Wiedemann, An. (Nys.) darlingi Root, and An. (N.) nuneztovari Gabaldón are considered to be the major malaria vectors in Colombia (Faran 1980, Herrera et al. 1987, Olano et al. 2001, Sierra et al. 2004). Other species considered to be of local or secondary vector importance include An. (Kertezia) lepidotus Zavortink, An. (K.) neivai Howard, Dyar \& Knab, An. (Anopheles) neomaculipalpus Curry, An. (Ano.) pseudopunctipennis Theobald, and An. (Ano.) punctimacula Dyar \& Knab (Ferro 1979, Carvajal et al. 1989, Olano et al. 2001, Moreno et al. 2005). In the Southern Colombian state of Putumayo, malaria cases due to Plamodium vivax are high (API 21-60 in last decade) yet neither An. albimanus nor An. nuneztovari are present. An. darlingi is present only as a limited population in the municipality of Puerto Leguízamo bordering the Colombian Amazonas (Fig. 1), where it is believed to be the vec-

Financial support: The Wellcome Trust (grant 053401), Colciencias (grant 1115-04-460-98)

${ }^{+}$Corresponding author: Y.Linton@nhm.ac.uk

${ }^{++}$Current address: Departmiento de Salud Publica, Faculdad de Medicina, Universidad National de Colombia, Bogotá, Colombia Received 15 February 2006

Accepted 28 June 2006 tor of a unique focus of $P$. falciparum in the region (OPS 2003). Of the known secondary vectors, only An. punctimacula has been detected, but it is present in such low numbers that it is not thought likely to be involved in malaria transmission in Putumayo. The most anthropophilic species is reported to be An. benarrochi $\mathrm{B}$ (Ruiz et al. 2005), followed by An. rangeli Gabaldón, Cova García \& López and An. oswaldoi (Peryassú) (Quiñones et al. 2000,2001 ), and thus it seems most likely that one or more of these three species may be involved in the transmission of $P$. vivax in Putumayo.

Previously An. evansae (Brèthes) (as An. noroestensis Galvao \& Lane) was reported from Putumayo and as it was highly anthropophilic and a vector in other areas of Latin America, it was suspected to be the main vector of malaria in Southern Colombia (Ferro 1979). However, recent studies by our team have shown that the species misidentified as An. evansae in Putumayo corresponds to a morphological variant of $A n$. benarrochi (Quiñones et al. 2001, Calle et al. 2002, Estrada et al. 2003), which was designated An. benarrochi B by Ruiz et al. (2005). Although the Colombian An. benarrochi is morphologically similar to that found in Peru, it differs morphologically and behaviorally from the nominotypical zoophilic $\mathrm{An}$. benarrochi found in Venezuela (Quiñones et al. 2001, Calle et al. 2002, Estrada et al. 2003, Ruiz et al. 2005).

An. benarrochi $\mathrm{B}$ is the most anthropophilic species in Putumayo and, therefore, is highly suspected to be the 
principal vector in this state (Quiñones et al. 2000, 2001). Recently, An. benarrochi s.l. was reported to be the dominant vector in the west of Loreto Province in Peru, which borders Putumayo (Aramburú et al. 1999, Schloeler et al. 2003), and recently Flores-Mendoza et al. (2004) reported that wild-caught An. benarrochi were vectors of both $P$. falciparum and P. vivax in Eastern Peru, with $0.14 \%$ (9 in 6323 pools containing 1-10 mosquitoes) ELISA positive. Barring one T insertion, Ruiz et al. (2005) showed that the second internal transcribed spacer (ITS2) sequences of Colombian An. benarrochi were identical to the GenBank entry AF055071 from Yurimaguas in Peru (misidentified as An. oswaldoi in Marrelli et al. 1999b), suggesting that these two highly anthropophilic populations comprise one species. The only other An. benarrochi sequences available in GenBank are from the state of Rondônia in Brazil (AF462383, AF462384, Marrelli et al. direct submissions 2001) and showed hugely distinct sequences from An. benarrochi B (15.4-16.3\%, ungapped). Close analysis showed these sequences are most similar to members of the An. nuneztovari complex. The male genitalia of $A n$. benarrochi $\mathrm{B}$ are morphologically distinct from those of An. benarrochi sensu Faran in the slide collections of the Smithsonian Institute (R Wilkerson \& Y-M Linton, unpublished). The discovery that An. benarrochi is a species complex of at least two species clarifies the conflicting reports of behavioral differences between the zoophilic concept of An. benarrochi s.s. and the anthropophilic profile of An. benarrochi B (Faran 1980, Rubio-Palis 2000). A P. vivax susceptibility trial with An. benarrochi specimens from Rondônia, Brazil proved negative (Klein et al. 1991).

An. oswaldoi is reported to be a species complex of at least four species in Latin America based on DNA sequences of the nuclear ITS2 (Marrelli et al. 1999b). However, the component species of the An. oswaldoi complex were not delineated by Marrelli et al. and subsequently one of these was shown to correspond to An. benarrochi B (Ruiz et al. 2005). In the Brazilian state of Acre, $A n$. oswaldoi is reportedly the most anthropophilic species and acts as an efficient vector (Branquinho et al. 1993, 1996, Marrelli et al. 1999a). More than 7\% (190/2610) of specimens tested by ELISA were positive: $3.41 \%$ for $P$. falciparum, $2.26 \%$ for $P$. vivax VK210, $1.22 \%$ for $P$. vivax VK247, and $0.42 \%$ for P. malariae (Branquinho et al. 1993). In a later study in the same area, $29 \%$ of specimens (1/34) were found positive by dissection of guts and salivary glands (Branquinho et al. 1996), suggesting that An. oswaldo $i$ is the principal vector of malaria in Acre. The species has also been found naturally infected in Peru (Hayes et al. 1987, Flores-Mendoza et al. 2004) and Venezuela (Rubio-Palis et al. 1992), but it is not considered to be an important vector in these countries, or in Colombia, due to its low densities.

An. rangeli is the third species of interest in Putumayo because of its apparent high densities and anthropophilic behaviour. Although this species is not thought to play a significant role in malaria transmission anywhere in Latin America (Faran 1980, Rubio-Palis 2000), ELISA detection studies carried out on specimens captured in CaquetaPutumayo between $1987-88$ showed that $6.2 \%$ of 419 tested positive for $P$. vivax VK210 circumsporozoite proteins by ELISA (Suárez et al. 1990). However, these results were never formally published, and no attempts have been undertaken to verify these results.

Given their high levels of anthropophily, it seems likely that An. benarrochi B, An. oswaldoi, and/or An. rangeli could be involved in malaria transmission in Putumayo. Morphologically, Anopheles mosquitoes of the subgenus Nyssorhynchus are notoriously difficult to identify as adult females, and yet this is the stage most commonly collected in epidemiological studies. Although adult females of An. rangeli are easy to identify, it was difficult to reliably separate the morphological variant $A n$. benarrochi $\mathrm{B}$ from those of An. oswaldoi in Colombia (Quiñones et al. 2001), except on the basis of egg morphology (Estrada et al. 2003). To facilitate rapid and accurate differentiation of these three species, a PCR-RFLP assay was designed in our laboratories for use in the present study (Ruiz et al. 2005), the objective of which was to incriminate the species of Anopheles mosquitoes likely to be responsible for the transmission of $P$. vivax in Putumayo. Identification of vector species, combined with ecological and behavioural data, will facilitate targeted malaria control strategies in the region.

\section{MATERIALS AND METHODS}

Mosquito collections - The Southern Colombian state of Putumayo is typified by humid tropical forest with an annual average temperature of $25.9^{\circ} \mathrm{C}$, relative humidity of $90 \%$ and annual average continuous rainfall of 4521 $\mathrm{mm}$. The state borders Ecuador and Peru in the south and the Colombian Amazon in the east (Fig. 1).

Human landing collections were carried out over 33 nights between 16 March 2000 and 11 October 2001. Human landing collections were carried according to the recommendations of the National Institute for Health (Colombia). Ethical clearance was obtained through the ethics committees of The Wellcome Trust and Colciencias, who both funded this study. Collections were carried out

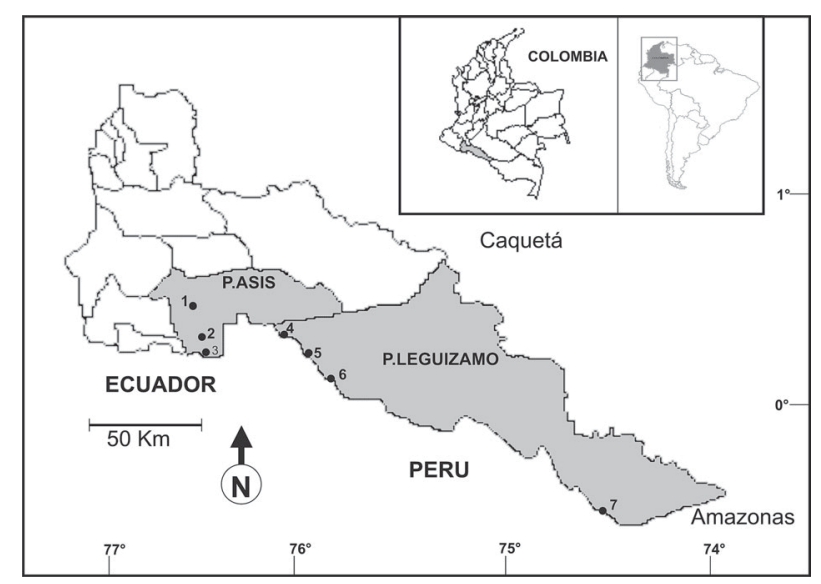

Fig. 1: map of Putumayo showing the seven localities sampled in the municipalities of Puerto Asís (1-3) and Puerto Leguízamo (47): 1. El Amaron, 2. La Manuela, 3. Toaya Abajo, 4. Piñuña Blanco, 5. Piñuña Negro, 6. La Concepción, 7. Puntales. 
in seven villages across two municipalities (Puerto Asís and Puerto Leguízamo), but due to civil unrest in the region, collections were sporadic and sampling was heavily biased towards the village of La Manuela, Puerto Asís (Table). Collections were carried out on the following dates: Puerto Asís, El Amaron $(\mathrm{n}=2)$, 16,17.vii.01; La Manuela $(\mathrm{n}=22), 16-22$. iii.00, 4,9-14.v.00, 13-17.vi.00, 26,29.i.01, 17,20.ii.01; Toaya Abajo $(\mathrm{n}=1), 15$.vii.01: Puerto Leguízamo, La Concepción $(\mathrm{n}=1)$, 9.v.01; Piñuña Blanco $(\mathrm{n}=3)$, 28,29.iv.01, 14.vii.01; Piñuña Negro $(\mathrm{n}=3)$, 1.v.01, 13,15.vii.01; Puntales ( $\mathrm{n}=1)$, 11.x.01 (Fig. 1, Table).

ELISA methods - Prior to ELISA detection of P. vivax (Wirtz et al. 1985, 1987), females were identified using the morphological keys of Faran (1980), Faran and Linthicum (1981), and Rubio-Palis (2000). Molecular confirmation of specimens identified as An. benarrochi and An. oswaldoi was carried out using the ITS2 PCR-RFLP described in Ruiz et al. (2005). Prior to ELISA, the head and thorax of each specimen were separated from the remaining body parts (wings, legs, and abdomens), which were stored as voucher specimens. Mosquito head/thorax sections were individually macerated and ELISA carried out following the standard protocol distributed with the ELISA kits (Centre for Disease Control, Atlanta, GA, US).

Mosquitoes were assayed in a 96-well ELISA plate, which also included seven negative controls consisting of colony An. albimanus and two positive mosquito samples. Results were read in an ELISA reader with a 415 $\mathrm{nm}$ filter, and rechecked after $1 \mathrm{~h}$. A value equivalent to twice the average of the negatives was used as a cut-off point as this was found to be most dependable in field evaluations (Beier et al. 1988). Confidence limits of the positive proportion were calculated under the assumption of a binomial distribution using the Epistat program (Gustafson 1989). To reduce the chance of reading false positives, all ELISA-positive individuals were retested at a later date. Stored abdomens of ELISA positive mosquitoes were subsequently used for molecular identification. Following the initial screening of 608 samples for both $P$. vivax VK210 and $P$. vivax VK247, no $P$. vivax VK247 was detected, thus all remaining specimens were tested for P. vivax VK210 only.

Molecular methods - Template DNA was acquired from the abdomens of mosquitoes using either the phenol-chloroform extraction protocol of Linton et al. (2001) or by placing a single leg directly into the PCR reaction. Amplification of the ITS2 was achieved using the 5.8SF and 28SR primers listed in Collins and Paskewitz (1996). PCR products were amplified using the reaction and thermocycler parameters described in Linton et al. (2001), and cleaned using the QIAgen PCR Purification Kit (QIAgen Ltd, Sussex, England), following the manufacturers instructions. Sequencing reactions were carried out in both directions using the Big Dye Terminator Kit (PE Applied Biosystems, Warrington, England) and sequence chromatograms were read by an ABI 377 automated sequencer (PE Applied Biosystems). Sequences were edited using Sequencher ${ }^{\mathrm{TM}}$ version 3.1.1 (Genes Codes Corporation, Ann Arbor, Michigan) and aligned in CLUSTAL X (Thompson et al. 1997). Similarity of the ITS2 sequences with those available in GenBank was compared using the Internet based FASTA search available at http:// www.ebi.ac.uk/fasta33/.

\section{RESULTS}

Wild-caught mosquitoes $(\mathrm{n}=2445)$ comprising 10 Anopheles species (Table) were tested for the presence of $P$. vivax circumsporozoite proteins. Thirty-six of the specimens $(1.5 \%)$ were found positive for $P$. vivax VK210, including An. oswaldoi $(\mathrm{n}=1)$ and An. rangeli $(\mathrm{n}=35)$ (Table). A total of $8.47 \%(35 / 413)$ of the An. rangeli and $0.27 \%$ (1/362) of the An. oswaldoi specimens were found to be naturally infected (Table). All 36 naturally infected

\section{TABLE}

Results of ELISA detection of Plasmodium vivax circumsporozoite proteins in 2445 wild-caught female mosquitoes captured landing on human bait in Putumayo between 16 March 2000 and 11 October 2001. Localities are numbered as follow: Puerto Asís: 1, El Amaron; 2, La Manuela; 3, Toaya Abajo; Puerto Leguizámo: 4, Piñuña Blanco; 5, Piñuña Negro; 6, La Concepción; 7 , Puntales. 95\% confidence intervals (CI) are shown for the percentages of infected specimens

\begin{tabular}{|c|c|c|c|c|c|}
\hline \multirow[b]{2}{*}{ Species } & \multirow[b]{2}{*}{ Localities } & \multirow{2}{*}{\multicolumn{2}{|c|}{$\begin{array}{l}\text { ELISA positives } \\
\text { (VK210) }\end{array}$}} & \multicolumn{2}{|c|}{ Minimum prevalence } \\
\hline & & & & Value & CI $(95 \%)$ \\
\hline Anopheles apicimacula $^{a}$ & 2 & 2 & - & - & - \\
\hline An. benarrochi ${ }^{b}$ & $1,2,3,4,5,6$ & 1617 & - & - & - \\
\hline An. darlingi ${ }^{a}$ & 7 & 29 & - & - & - \\
\hline An. mattogrosensis & 4 & 7 & - & - & - \\
\hline An. neomaculipalpus $b$ & 2,4 & 7 & - & - & - \\
\hline An. oswaldoi $b$ & $1,2,3,4,5,6,7$ & 362 & 1 & $2.76 \%$ & $0.1-21.9$ \\
\hline An. peryassui & 7 & 1 & - & - & - \\
\hline An. punctimacula ${ }^{a}$ & 4 & 1 & - & - & - \\
\hline An. rangeli & $1,2,3,4,5,6$ & 413 & 35 & $8.47 \%$ & $5.6-11.2$ \\
\hline An. triannulatus & 2,5 & 6 & - & - & - \\
\hline Total & & 2445 & 36 & & \\
\hline
\end{tabular}

$a$ : species reported or suspected to act as primary or secondary malaria vectors in Colombia; $b$ : species incriminated in malaria transmission in other regions of Latin America. 
specimens were collected in the village of La Manuela in the municipality of Puerto Asís, Putumayo from 16-22 March 2000. To verify the morphological identification, nuclear ITS2 rDNA sequences were generated for 31 of the 36 specimens.

The ITS2 sequence generated for the positive specimen of An. oswaldoi s.l. (GenBank accession AY679155) was 531 bp long (Fig. 2). The sequence was identical to those previously reported for An. oswaldoi from Putumayo (AY679149-154, Ruiz et al. 2005) and shared 99.2\% similarity with those of An. oswaldoi from Santana, Amapá, Brazil (AF056318) and Ocama, state of Amazonas, Venezuela (AF055070) (Marrelli et al. 1999a,b). Pairwise sequence alignment of An. rangeli and An. oswaldoi was $539 \mathrm{bp}$ and interspecific variation was $88.9 \%(92.2 \%$ ungapped) (Fig. 2).

$1 \quad 1111111112 \quad 2222222223 \quad 3333333334 \quad 4444444445 \quad 5555555556$ $\begin{array}{lllllll}1234567890 & 1234567890 & 1234567890 & 1234567890 & 1234567890 & 1234567890\end{array}$ oswaldoi(1) atcactcggc tcgtggatcg atgaagaccg cagctaaatg cgcgtcagaa tgtgaactgc

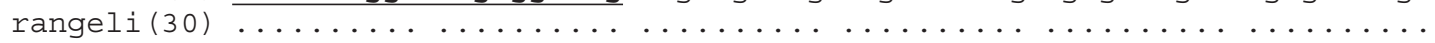

$1 \quad 1111111111 \quad 1111111111$ $66666666677777777778 \quad 888888888999999999900000000001 \quad 1111111112$ $\begin{array}{lllllll}1234567890 & 1234567890 & 1234567890 & 1234567890 & 1234567890 & 1234567890\end{array}$ oswaldoi(1) aggacacatg aacaccgaca cgttgaacgc atattgcgca ttgcacgact cagtgcgatg

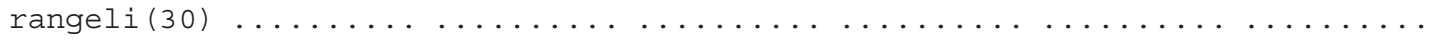

$111111111111111111111111111111 \quad 1111111111 \quad 11111111111111111111$ $2222222223 \quad 3333333334 \quad 4444444445 \quad 5555555556 \quad 6666666667 \quad 7777777778$ $\begin{array}{lllllll}1234567890 & 1234567890 & 1234567890 & 1234567890 & 1234567890 & 1234567890\end{array}$ oswaldoi(1) tacacatttt tgagtgccca cattcaccgc agaaccaact agcatagccg tcgaaagctt rangeli $(30) \ldots \ldots \ldots \ldots \ldots \ldots \ldots \ldots \ldots \ldots \ldots \ldots \ldots \ldots \ldots \ldots \ldots \ldots \ldots . . . \ldots \ldots$

$\begin{array}{lllllll}111111111 & 1111111112 & 2222222222 & 2222222222 & 2222222222 & 2222222222\end{array}$ $888888888999999999900000000001 \quad 1111111112 \quad 2222222223 \quad 3333333334$ $\begin{array}{lllllll}1234567890 & 1234567890 & 1234567890 & 1234567890 & 1234567890 & 1234567890\end{array}$ oswaldoi(1) tgctgcgtac tgatgattgg ttgaccat-g tgccaaccaa gcattgaagg actgtggcgt

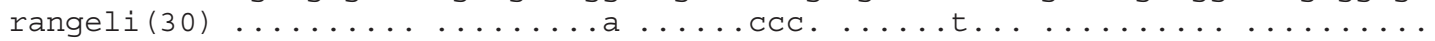

$2222222222 \quad 2222222222 \quad 2222222222 \quad 2222222222 \quad 2222222222 \quad 2222222223$ $44444444455555555556 \quad 6666666667 \quad 7777777778 \quad 88888888899999999990$ $\begin{array}{lllllll}1234567890 & 1234567890 & 1234567890 & 1234567890 & 1234567890 & 1234567890\end{array}$ oswaldoi(1) ggtgggtgca ccgtgtgtgt gtcgttgctt aatacgactc attctctggt atcacatctg

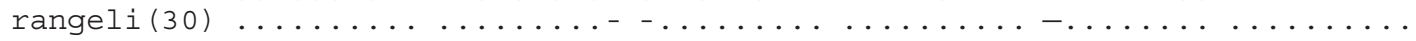

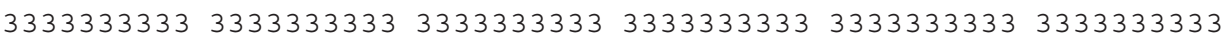
$0000000001 \quad 1111111112 \quad 2222222223 \quad 3333333334 \quad 44444444455555555556$ $\begin{array}{lllllll}1234567890 & 1234567890 & 1234567890 & 1234567890 & 1234567890 & 1234567890\end{array}$ oswaldoi(1) gagcgggcta tccagtcaca atccccagcg acatgtgc- aca-gatagc cccgatgtgg

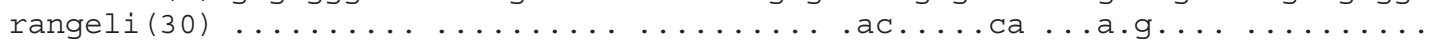
$\begin{array}{lllllll}3333333333 & 3333333333 & 3333333333 & 3333333334 & 4444444444 & 4444444444\end{array}$ $66666666677777777778 \quad 888888888999999999900000000001 \quad 1111111112$ $\begin{array}{lllllll}1234567890 & 1234567890 & 1234567890 & 1234567890 & 1234567890 & 1234567890\end{array}$ oswaldoi(1) ag-gaccat cctccctcaa agccagccca tgtgatac-a cacaaacgga gcgagaccaa rangeli(30) ..aa..t..t............t........c...c............. $4444444444 \quad 4444444444 \quad 4444444444 \quad 4444444444 \quad 4444444444 \quad 4444444444$ $2222222223 \quad 3333333334 \quad 4444444445 \quad 5555555556 \quad 6666666667 \quad 7777777778$ $\begin{array}{lllllll}1234567890 & 1234567890 & 1234567890 & 1234567890 & 1234567890 & 1234567890\end{array}$ oswaldoi(1) acgtaccctg aagcaacgta tgcgcacacg cgtgcagctc attgaagcgc gcacgatcga rangeli(30) ..............g.ca.tg.............cc.c.tt...t.-c.tt

$4444444444 \quad 44444444455555555555 \quad 5555555555 \quad 5555555555 \quad 555555555$ $888888888999999999900000000001 \quad 1111111112 \quad 2222222223 \quad 333333333$ $\begin{array}{lllllll}1234567890 & 1234567890 & 1234567890 & 1234567890 & 1234567890 & 123456789\end{array}$ oswaldoi(1) aagagaaccg at-caagtgg gcctcaaata atgtgtgact acccctaaa tttaagcat rangeli(30) ctc..cg.ga .ca...........................

Fig. 2: a 539 bp alignment of the nuclear ITS2 region of 31 of the 36 specimens found to be positive for Plasmodium vivax VK210 by ELISA. The alignment includes Anopheles oswaldoi $(\mathrm{n}=1)$ and Anopheles rangeli $(\mathrm{n}=30)$. Primer sequences are in boldface and are underlined. 
No intraspecific variation was noted in the 30 specimens of ELISA positive An. rangeli (529 bp) and another 27 specimens of these species sequenced from progeny broods from Putumayo (DQ666854-DQ666910). This ITS2 sequence was compared to others for An. rangeli available in GenBank: U92329 (Danoff-Burg \& Conn, direct submission 1997) of unknown origin, Y09239 (Fritz 1998 which is a consensus sequence of nine An. rangeli specimens from Bolivia (San Ramon, Beni State, $n=3$ ), Brazil (Senador Guiomard, Acre, $\mathrm{n}=1$ ), Ecuador (Coca, Napo, $\mathrm{n}=4$ ) and Venezuela (Veguita, Barinas, $\mathrm{n}=1$ ), as well as AF462381 \& AF462382 from Acre, Brazil (Marrelli et al. direct submission 2002). Because some of these sequences are considerably shorter than ours, an alignment corresponding to the shortest sequence (U92329, $348 \mathrm{bp}$ ) was created that corresponded to bases 145-501 in Fig. 2 (Fig. $3)$. This alignment revealed that our 57 An. rangeli sequences from Putumayo share 100\% identity with Y09239 and U92329 from Bolivia, Northern Brazil, Ecuador, and Venezuela. These sequences exhibit four fixed differences from the two An. rangeli sequences from Acre, Brazil (AF462381, AF462382) at base $457(\mathrm{~A} / \mathrm{T})$, base $491(\mathrm{~A} / \mathrm{G})$ and a 2-bp indel event (CG) at bases 488 and 489. In addition, an indel (A) is unique to sequence AF462382 between bases 444-445.

$\begin{array}{ll} & 23333 \\ & 90333 \\ & 14568 \\ \text { rangeli (60) } & - \text { acga } \\ \text { Y09239 } & -\ldots . \\ \text { U92329 } & -\ldots . \\ \text { AF462382 } & \text { at--g } \\ \text { AF462381 } & -t--g\end{array}$

Fig. 3: a 348 bp alignment of all Anopheles rangeli sequences generated from Putumayo $(n=57)$ and those available in GenBank: U92329 of unknown origin (Danoff-Burg \& Conn, direct submission 1997), Y09239 (Fritz 1998) - a consensus sequence of nine An. rangeli specimens from Bolivia (San Ramon, Beni State, $\mathrm{n}=3$ ), Brazil (Senador Guiomard, Acre, $\mathrm{n}=1$ ), Ecuador (Coca, Napo State, $\mathrm{n}=4$ ), Venezuela (Veguita, Barinas State, $\mathrm{n}=1$ ), and AF462381 \& AF462382 from Acre, Brazil (Marrelli et al., direct submission 2002). Due to differing lengths of GenBank entries and our amplified fragment, this alignment corresponds to bases 145-501 of Fig. 2.

\section{DISCUSSION}

In this study, 35 An. rangeli and 1 An. oswaldoi were found naturally infected with $P$. vivax VK210, supporting the incrimination of two novel malaria vectors in Colombia. All positive specimens were collected in the space of a single week (16-22 March 2000) in La Manuela, Puerto Asís. Although this may seem curious at first, the raw data confirm that these 36 positive mosquitoes were detected in six of the 31 ELISA plates processed, on four separate days. All positive individuals were subsequently retested to discount contamination. Careful analysis of the raw data showed that 551 mosquitoes $(22.5 \%$ of those tested) were captured during the same week, thus the data are heavily biased towards this weeks collection. Due to civil unrest, collections were heavily skewed towards La
Manuela in Puerto Asís and two-thirds of all night biting collections in this study took place in this village. Although little is known about the distribution and seasonality of malaria in Putumayo, the main transmission season does coincide with early spring, when all the $P$. vivax positive mosquitoes were found.

Of the 413 specimens of An. rangeli tested, 8.47\% were positive for P. vivax VK210. That An. rangeli appears to be a malaria vector in Putumayo confirms the unpublished findings of Suarez et al. (1990). They reported $6.2 \%$ of An. rangeli from Caqueta-Putumayo to be ELISA positive for $P$. vivax - a similar rate to that found in this study. Among specimens of An. rangeli from Peru, Hayes et al. (1987) reported that $0.4 \%(2 / 480)$ were sporozoitepositive in the dissected salivary glands. Circumsporozoite proteins of P. malariae have also been reported in An. rangeli from Amapá, Brazil (Povoa et al. 2001), but because of its low density and predominantly zoophilic behaviour, the species is not considered to be of vector significance in Brazil. In contrast, blood meal determination of An. rangeli in western Venezuela revealed a human blood index of $30.8-40 \%$, which was significantly higher than for An. nuneztovari, the principle vector (Rubio-Palis et al. 1994). That An. rangeli appears to be the principal local malaria vector in Putumayo, despite its relatively low abundance, suggests that its vectorial importance across its range of distribution could perhaps be masked by the presence of better-known vectors. The importance of An. rangeli in the natural transmission of malaria needs now to be fully assessed in other regions of Colombia and across Latin America.

One specimen of An. oswaldoi was found to be positive for $P$. vivax VK210 in this study. Comparisons of the ITS2 sequence of this specimen with ITS2 sequences in GenBank showed $100 \%$ identity to other An. oswaldoi from Putumayo (AY679149-AY679154) (Ruiz et al. 2005), 99.2\% identity to AF056318 from Amapá, Brazil and AF055070 from Ocamo, Amazonas, Venezuela (Marrelli et al. 1999b). This study shows that this genetically identifiable species of the An. oswaldoi complex are likely to be involved in P. vivax transmission and may therefore be of importance elsewhere within its range of distribution.

Susceptibility trials of An . benarrochi from Rondônia, Brazil to $P$. vivax proved negative (Klein et al. 1991), contrasting with reports of a highly anthropophilic $A n$. benarrochi acting as a vector in Peru (Aramburú et al. 1999, Schloeler et al. 2003, Flores-Mendoza et al. 2004). Given the morphological similarities between Colombian $A n$. benarrochi $\mathrm{B}$ and specimens identified as $A n$. benarrochi that vectors malaria in Peru ( $\mathrm{R}$ Wilkerson \& C Flores-Mendoza, pers. commun.), we assumed these highly anthropophilic populations comprised the same species. Comparison of ITS2 sequence with dissected male genitalia of voucher specimens, showed that $A n$. benarrochi from Peru comprises two morphological forms, one that matches the original description of the species (i.e. An. benarrochi s.s.) and another that corresponds to the Southern Colombian An. benarrochi B of Ruiz et al. (2005) (Wilkerson, Flores-Mendoza \& Linton, unpublished). Despite being the most prevalent anthropophilic species captured in Putumayo, comprising $66.1 \%$ of all 
mosquitoes tested, An. benarrochi B was not found naturally infected in this study (Table). Efforts are now underway in our laboratory to formally describe and name $A n$. benarrochi $\mathrm{B}$, and it is now prudent to use molecular methods to examine populations of An. benarrochi s.l. across Latin America to ascertain their taxonomic identity.

Given the natural infection of An. oswaldoi reported herein, and the contrasting vector incrimination results of the highly anthropophilic, morphological variant of $A n$. benarrochi in Putumayo and neighboring Peru with those elsewhere, it its important to correlate vector incrimination with the taxonomic and genetic identity of these two species in future studies to avoid further confusion. The taxonomic identity of An. rangeli is also now under some question, with two very different ITS2 sequences detected in Colombia and Brazil. Incorrect species identification hampers malaria control efforts, and it is clear from this study that efforts must be made to understand the biology and behaviour of genetically identified vectors as a prerequisite to effective malaria control.

\section{ACKNOWLEDGEMENTS}

To Dr Ivan Dario Vélez and Dr William Galarza and the entomology teams at PECET and DASALUD.

\section{REFERENCES}

Aramburú GJ, Ramal AC, Witzig R 1999. Malaria re-emergence in the Peruvian Amazon region. Emerg Infec Dis 5: 209215 .

Beier JC, Asiago CM, Onyango FK, Koros JK 1988. ELISA absorbance cut-off method affects malaria sporozoite rate determination in wild Afrotropical Anopheles. Med Vet Entomol 2: 259-264.

Branquinho MS, Araujo D, Natal MT, Marrelli RM, Rocha FAL, Taveira JK, Kloetzel JK 1996. Anopheles oswaldoi a potential malaria vector in Acre, Brazil. Trans $R$ Soc Trop Med Hyg 90: 233.

Branquinho MS, Taipe Lagos CB, Rocha RM, Natal D, Barata JMS, Cochrane AH, Nardin E, Nussenzweig RS, Kloetzel JK 1993. Anophelines in the State of Acre, Brazil, infected with Plasmodium falciparum, $P$. vivax, the variant $P$. vivax VK247 and P. malariae. Trans $R$ Soc Trop Med Hyg 87: 391-394.

Calle D, Quiñones ML, Erazo H, Jaramillo N 2002. Morphometric discrimination of females of five species of Anopheles of the subgenus Nyssorhynchus Blanchard (Diptera: Culicidae) in Colombia. Mem Inst Oswaldo Cruz 97: 11911195.

Carvajal H, de Herrera MA, Quintero J, Alzate A, Herrera S 1989. Anopheles neivai: a vector of malaria in the Pacific lowlands of Colombia. Trans R Soc Trop Med Hyg 83: 609.

Collins FH, Paskewitz SM 1996. A review of the use of ribosomal DNA (rDNA) to differentiate among cryptic Anopheles species. Insect Mol Biol 5: 1-9.

Estrada DA, Quiñones ML, Sierra DM, Calle DA, Ruiz F, Erazo HF, Linton Y-M 2003. Utilidad de la morfología de los huevos como un método indirecto para identificar Anopheles benarrochi Gabaldón, Cova García \& López, Anopheles oswaldoi (Peryassú) y Anopheles rangeli Gabaldón,
Cova García \& López, (Diptera: Culicidae) en Putumayo, Colombia. Biomédica 23: 388-395.

Faran ME 1980. Mosquito studies (Diptera, Culicidae) XXXIV. A revision of the Albimanus Section of the subgenus Nyssorhynchus of Anopheles. Contrib Am Entomol Inst 15: $1-215$.

Faran ME, Linthicum KJ 1981. A handbook of the Amazonian species of Anopheles (Nyssorhynchus) (Diptera: Culicidae). Mosq Syst 13: 1-81.

Ferro CA. 1979. Revisión de los recursos aplicables a la lucha contra el Paludismo. Rev Esc Nal Salud Pub Colombia 5: $11-18$.

Flores-Mendoza C, Fernandez R, Escobedo-Vargas KS, VelaPerez Q, Schoeler GB 2004. Natural Plasmodium infections in Anopheles darlingi and Anopheles benarrochi (Diptera: Culicidae) from eastern Peru. J Med Entomol 41: 489-494.

Fritz GN 1998. Sequence analysis of the rDNA internal transcribed spacer 2 of five species of South American human malaria mosquitoes. DNA Seq 8: 215-221.

Gustafson TL 1989. True Epistat, 4th ed., Epistat Services, Richardson, Texas.

Hayes J, Calderon G, Falcon R, Zambrano V 1987. Newly incriminated Anopheles vectors of human malaria parasites in Junin Department, Peru. J Am Mosq Control Assoc 33: 418-422.

Herrera S, Suárez MF, Sanchez GI, Quiñones ML, de Herrera M 1987. Uso de la técnica radioinmunoensayo IRMA en Anopheles de Colombia para la detección de esporozoitos de Plasmodium. Colombia Médica 18: 2-6.

Klein TA, Lima JP, Tada MS, Miller R 1991. Comparative susceptibility of anopheline mosquitoes in Rondônia, Brazil to infection with Plasmodium vivax. Am J Trop Med Hyg 45: 463-470.

Linton Y-M, Harbach RE, Anthony TG, Chang MS, Asmad M 2001. Morphological and molecular identity of Anopheles (Cellia) sundaicus (Diptera: Culicidae), the nominotypical member of a malaria vector species complex in Southeast Asia. Syst Entomol 26: 357-366.

Marrelli MT, Honorio NA, Flores-Mendoza C, Lourenco-deOliveira R, Marinotti O, Kloetzel JK 1999a Comparative susceptibility of two members of the Anopheles oswaldoi complex, An. oswaldoi and An. konderi, to infection by Plasmodium vivax. Trans $R$ Soc Trop Med Hyg 93: 381384.

Marrelli MT, Malafronte RS, Flores-Mendoza C, LourençoDe-Oliveira R, Kloetzel JK, Marinotti O 1999b. Sequence analysis of the second internal transcribed spacer of ribosomal DNA in Anopheles oswaldoi (Diptera: Culicidae). J Med Entomol 36: 679-684.

Moreno JE, Rubio-Palis Y, Paez E, Perez E, Sanchez V, Vaccari E 2005. Anopheles (Anopheles) neomaculipalpus: a new malaria vector in the Amazon basin? Med Vet Entomol 19: 329-332.

Olano VA, Brochero HL, Saenz R, Quiñones ML, Molina J 2001. Mapas preliminares de la distribución de especies de Anopheles vectores de malaria en Colombia. Biomédica 21: 402-408. 
OPS-Organización Panamericana de la Salud 2003. http:// www.col.ops-oms.org/sivigila/2003

Povoa MM, Machado RL, Segura MN, Vianna GM, Vasconcel AS, Conn JE 2000. Infectivity of malaria vector mosquitoes: correlation of positivity between ELISA and PCRELISA tests. Trans R Soc Trop Med Hyg 94: 106-107.

Povoa MM, Wirtz RA, Lacerda RNL, Miles MA, Warhust D 2001. Malaria vectors in the municipality of Serra do Navio, state of Amapá, Amazon Region, Brazil. Mem Inst Oswaldo Cruz 96: 179-184

Quiñones ML, Harbach RE, Calle DA, Ruiz F, Erazo HF, Linton Y-M. 2001 Variante morfológica de adultos hembras de Anopheles benarrochi (Diptera: Culicidae) en Putumayo, Colombia. Biomédica 21:351-359.

Quiñones ML, Linton Y-M, Harbach RE, Estrada DA, Erazo HF, Calle DA, Ruiz JF 2000. Malaria species in southern Colombia: species determination and natural infectivity. XV International Congress for Tropical Medicine and Malaria, Cartagena de Indias, Colombia, August 20-25, Abstract Book, Vol. 1, p. 108.

Rubio-Palis Y 2000. Anopheles (Nyssorhynchus) de Venezuela: Taxonomía, Bionomía, Ecología e Importancia Médica, Escuela Malariol San Amb, Maracay, Venezuela, 120 pp.

Rubio-Palis Y, Curtis CF, Gonzalez C, Wirtz RA 1994. Host choice of Anopheline mosquitoes in a malaria endemic area of western Venezuela. Med Vet Entomol 8: 275-280.

Rubio-Palis Y, Wirtz RA, Curtis CF 1992. Malaria entomological inoculation rates in western Venezuela. Acta Trop 52: 167-174.
Ruiz F, Quiñones ML, Erazo HF, Calle DA, Alzate JF, Linton Y-M 2005. Molecular differentiation of Anopheles (Nyssorhynchus) benarrochi and An. (N.) oswaldoi in Southern Colombia. Mem Instituto Oswaldo Cruz 100: 155-160.

Schoeler GB, Flores-Mendoza C, Fernández R, Davila JR, Zyzak M 2003. Geographical distribution of Anopheles darlingi (Diptera: Culicidae) in the Amazon Basin region of Peru. J Am Mosq Control Assoc 19: 286-296.

Sierra DM, Velez ID, Linton Y-M 2004. The malaria vector Anopheles (Nyssorhynchus) nuneztovari Gabaldon comprises one genetic species in Colombia based on homogeneity of nuclear ITS2 rDNA. J Med Entomol 41: 302-307.

Suárez MF, Quiñones ML, Wirtz RA 1990. Anopheles rangeli - A suspected vector of Plasmodium vivax in southern Colombia. The 39th Annual Meeting of the American Society of Tropical Medicine and Hygiene, New Orleans, Abstract Booklet, p. 158.

Thompson JD, Gibson TJ, Plewniak F, Jeanmougin F, Higgins, DG 1997. The Clustal X windows interface: flexible strategies for multiple sequence alignment aided by quality analysis tools. Nucleic Acid Res 24: 4876-4882.

Wirtz RA, Burkot TR, Andre RG, Rosenberg R, Collins WE, Roberts DR 1985. Identification of Plasmodium vivax sporozoites in mosquitoes using an enzyme-linked immunosorbent assay. Am J Trop Med Hyg 34: 1048-1054.

Wirtz RA, Zavala F, Charoenvit Y, Campbell GH, Burkot TR, Schneider I, Esser KM, Beaudoin RL, Andre RG 1987. Comparative testing of monoclonal antibodies against Plasmodium falciparum sporozoites for ELISA development. Bull WHO 65: 39-45. 
